\title{
Growth and organic solutes accumulation in seedlings of Caatinga tree species in response of water deficit and potassium
}

Drought stress negatively influences a variety of essential physiological process for plant growth and biomass production, and potassium contributes to the absorption of water and maintaining cell turgor, being crucial to understand the seedlings water stress responses. This research aimed to verify the effects to water deficiency and potassium on the growth and accumulation of organic solutes in Myracrodruon urundeuva, Libidibia ferrea, and Mimosa tenuiflora. The treatments were distributed in a $3 \times 3$ factorial scheme, with three water levels ( $100 \% \mathrm{pc}$ - control, $50 \% \mathrm{pc}$ - moderate water deficit, and $25 \% \mathrm{pc}$ - severe water deficit) and three doses of potassium $(0,97.5$ and $195 \mathrm{mg} \mathrm{dm}-3 \mathrm{~K})$. The plants were sown in black plastic bags, containing $5 \mathrm{~kg}$ of soil. Were evaluated plant height, stem diameter, and leaf concentrations of total soluble sugars, total free amino acids, and proteins. The water deficit caused a reduction in the growth of $\mathrm{M}$. urundeuva and $\mathrm{M}$. tenuiflora plants, regardless of the added potassium. The plants of $M$. urundeuva and $M$. tenuiflora were not demanding in potassium, while potassium fertilization with $97.5 \mathrm{mg} \mathrm{dm}-3 \mathrm{~K}$ favored L. ferrea plants, especially when kept under moderate water deficit. The moderate water deficit promoted accumulation of total free amino acids and soluble proteins in M. urundeuva, while in L. ferrea there was accumulation of total free amino acids under severe water deficit. Increase in the potassium promoted reduction in the concentrations of total soluble sugars and soluble proteins.

Keywords: Mineral Nutrition; Osmotic Adjustment; Water Stress.

\section{Crescimento e acúmulo de solutos orgânicos em mudas de espécies arbóreas da Caatinga em resposta ao déficit hídrico e potássio}

\begin{abstract}
O estresse hídrico influencia negativamente uma variedade de processos fisiológicos essenciais para o crescimento das plantas e a produção de biomassa, e o potássio contribui para a absorção de água e, assim, mantém o turgor celular, sendo crucial para entender as respostas das mudas ao estresse hídrico. Nesse contexto, esta pesquisa teve como objetivo verificar os efeitos da deficiência de água e potássio no crescimento e acúmulo de solutos orgânicos em Myracrocruon urundeuva, Libidibia ferrea e Mimosa tenuiflora. Os tratamentos foram distribuídos em esquema fatorial $3 \times 3$, com três níveis de água ( $100 \% \mathrm{cp}$ - controle, $50 \%$ $\mathrm{cp}$ - déficit hídrico moderado e $25 \% \mathrm{cp}$ - déficit hídrico severo) e três doses de potássio (0,97,5 e $195 \mathrm{mg} \mathrm{dm}-3 \mathrm{~K})$. As plantas foram semeadas em sacos plásticos pretos, contendo $5 \mathrm{~kg}$ de solo. Foram avaliadas a altura da planta, o diâmetro do caule e as concentrações foliares de açúcares solúveis totais, aminoácidos livres totais e proteínas. O déficit hídrico causou uma redução no crescimento das plantas de $\mathrm{M}$. urundeuva e M. tenuiflora, independentemente da adição de potássio. As plantas de M. urundeuva e M. tenuiflora não exigiam potássio, enquanto a fertilização com $97,5 \mathrm{mg} \mathrm{dm}-3 \mathrm{~K}$ favoreceu as plantas de L. ferrea, principalmente quando mantidas em déficit hídrico moderado. O déficit moderado de água promoveu o acúmulo de aminoácidos livres totais e proteínas solúveis em $\mathrm{M}$. urundeuva, enquanto em L. ferrea houve acúmulo de aminoácidos livres totais sob déficit hídrico grave. O aumento do potássio promoveu redução nas concentrações de açúcares solúveis totais e proteínas solúveis.
\end{abstract}

Palavras-chave: Ajustamento Osmótico; Estresse Hídrico; Nutrição Mineral.

Topic: Ciências Florestais

Reviewed anonymously in the process of blind peer.
Received: 03/02/2021

Approved: 27/02/2021
Ediglécia Pereira Almeida (iD

Universidade Federal de Campina Grande, Brasil

http://lattes.cnpq.br/0708558267291365

http://orcid.org/0000-0003-1625-8180

ediglecia.almeida@hotmail.com

Antonio Lucineudo de Oliveira Freire (i)

Universidade Federal de Campina Grande, Brasil

http://lattes.cnpq.br/2075103387003003

http://orcid.org/0000-0002-6477-8554

lucineudofreire@gmail.com

Ivonete Alves Bakke (iD)

Universidade Federal de Campina Grande, Brasil

http://lattes.cnpq.br/9726626914770477

http://orcid.org/0000-0002-6015-6977

ivobakke@gmail.com

\author{
Cheila Deisy Ferreira (iD) \\ Universidade Federal de Campina Grande, Brasil \\ http://lattes.cnpq.br/7018848134050014 \\ http://orcid.org/0000-0003-1346-9214 \\ cheiladeisy@yahoo.com.br \\ George Martins de França (iD \\ Universidade Federal de Campina Grande, Brasil \\ http://lattes.cnpq.br/0661906391252675 \\ http://orcid.org/0000-0002-4249-4534 \\ george.martins.aurora9@gmail.com \\ Antonio Wesly Batista (iD \\ Universidade Federal de Campina Grande, Brasil \\ http://lattes.cnpq.br/4188540452184378 \\ http://orcid.org/0000-0002-0113-6116 \\ weslleybatista02@gmail.com
}

Referencing this:

ALMEIDA, E. P.; FREIRE, A. L. O.; BAKKE, I. A.; FERREIRA, C. D.; FRANÇA, G. M.; BATISTA, A. W.. Growth and organic solutes accumulation in seedlings of Caatinga tree species in response of water deficit and potassium. Revista Ibero Americana de Ciências Ambientais, v.12, n.2, p.57-67, 2021. DOI: http://doi.org/10.6008/CBPC21796858.2021 .002 .0007

DOI: 10.6008/CBPC2179-6858.2021.002.0007 


\section{INTRODUCTION}

The climate changes resulting from global warming will promote an increase in cycles, intensity and periods of drought (IPCC, 2014), affecting the composition, structure and production of forests (ALLEN et al., 2010).

The semiarid region located in the northeast region of Brazil, is characterized by a period of 3 to 5 months of rain, irregularly distributed, with high temperatures and light intensity, causing high evaporation rates, remaining in the vegetation subject to a water deficit during most of the year (TROVÃO et al., 2007). The Caatinga, located in this semi-arid region, is a tropical forest with a dry climate, with $844,453 \mathrm{~km}^{2}$ (BRASIL, 2008; GUSMÃO et al., 2016), has a typical vegetation, with particular, ecological and mainly floristic characteristics, characterized by branched trees and shrubs, with deciduous foliage in the dry season, in addition to the wide variety of bromeliads and spiny cacti (MAIA, 2004; QUEIROZ et al., 2005). To survive under such conditions, during the rainy season, Caatinga vegetation develops resources that allow maximum absorption and accumulation of water, such as deep root system and tuberous root, and during the period of low water availability, the reduction in loss of water, including stomatal closure, high water use efficiency and osmotic adjustment (ALVES et al., 2009b; BARROS et al., 2013).

In order to ensure water absorption and, in this way, maintain cellular water status without affecting metabolism, plants develop osmotic adjustment through the synthesis and accumulation of low molecular weight metabolites (DICHIO et al., 2009; NIO et al., 2011). The amount and type of accumulated solute depends on the plant species and the length of the deficit period. Among the metabolites that contribute to osmotic adjustment, soluble sugars and amino acids such as glycine betaine (RHODES et al., 1993) and proline (SZABADOS et al., 2010; ALBUQUERQUE et al., 2013) can be mentioned.

In addition to these solutes, some ions such as $\mathrm{K}^{+}$act to exert this osmotic effect within plants (BATTIE-LACLAU et al., 2014), contributing to the absorption of water and thus maintaining cell turgor, which guarantees the maintenance of the necessary physiological processes the plants. Research indicates that potassium has produced positive effects in mitigating the effects of water deficit on plant development (MONDINI et al., 2019), however studies with this scope for species in the Caatinga are still incipient.

However, potassium excess interfers in other cations absorption (PRADO, 2008; TAIZ et al., 2013), and under high concentrations, it can have a harmful effect on the plant, affecting cell membranes or proteins structures (MELO et al., 2020). The potassium chloride osmotic effects has been noticed, causing plasmolysis, reducing germination (OLIVEIRA et al., 2019), survival and growth and biomass production of plants (MELO et al., 2020).

The Libidibia ferrea (Mart. Ex Tul), Mimosa tenuiflora (Willd), from the family Fabaceae, and Myracrodruon urundeuva Fr. Allemão, family Anacardiaceae, are representative of the Caatinga, being widely distributed. L. ferrea is a colonizer of secondary stages (LORENZI, 2008) while M. tenuiflora is a pioneer species (AZEVÊDO et al., 2012), both are used for energy purposes and wood production (CARVALHO, 2003; OLIVEIRA, 2003; LORENZI, 2008), in addition to having medicinal properties (SAMPAIO et al., 2009; OLIVEIRA 
et al., 2010) and the restoration of degraded areas (AZEVÊDO et al., 2012; JESUS et al., 2017). M. urundeuva is a colonizer of late secondary stages (LORENZI, 2008), has pharmacological properties (LUCENA et al., 2011; RIBEIRO et al., 2014) and high wood potential, in addition to being used for the production of tannin, used in leather tanning (MONTEIRO et al., 2005). Due to its diversity of uses, it was explored in an intense and indiscriminate manner in the semi-arid region of Brazil, which resulted in its inclusion in the official list of the Ministério do Meio Ambiente of endangered species (BRASIL, 2008).

Despite the high biological importance for the Caatinga, little is known about the physiological responses of these species under water deficit, especially during the seedling phase the most vulnerable phase of the forest tree life (JAMNICKÁ et al., 2019). Due to its climatic and pedological characteristics, the semi-arid region where the Caatinga is inserted presents itself as extremely susceptible to the changes resulting from the climate changes expected as a result of global warming. Thus, understanding the strategies used by the species of the Caatinga is essential to maintain the biodiversity of this biome in future scenarios.

In this context, this research aimed to evaluate growth and organic solutes accumulations in three species in Caatinga plants under water deficit, fertilized with potassium.

\section{MATERIALS E METHODS}

The research was carried out in Forest Nursery of the Academic Unity of Forest Engineering, Universidade Federal de Campina Grande, Patos, Paraiba State, Brazil ( $7^{\circ} 03^{\prime} 34^{\prime \prime}$ S, $37^{\circ} 16^{\prime} 30^{\prime \prime}$ O), in lateral screened structure and plastic cover.

The seeds came from were obtained from trees growing on the Campus, and before sowing, the seeds of $L$. ferrea and $M$. tenuiflora were subjected to break of tegumentary dormancy using sulfuric acid for 30 minutes (ALVES et al., 2009a) and immersion in hot water $\left(85^{\circ} \mathrm{C}\right.$ ) for 30 seconds (BAKKE et al., 2006). They were sown in black plastic bags, containing $5 \mathrm{~kg}$ of soil from the $0.0-0,20 \mathrm{~m}$ in ground spoil layer. The chemical analysis indicated that the soil had pH ( $\left.\mathrm{H}_{2} \mathrm{O}\right) 6.5 ; \mathrm{P}$ (Mehlich) $2.9 \mathrm{mg} \mathrm{kg}^{-1} ; \mathrm{Ca}^{2} .0 \mathrm{cmol}_{\mathrm{c}} \mathrm{dm}^{-3} ; \mathrm{Mg} 2.0 \mathrm{cmol}_{\mathrm{c}} \mathrm{dm}^{-}$ 3; $\mathrm{K} 0,7 \mathrm{cmol}_{\mathrm{c}} \mathrm{dm}^{-3} ; \mathrm{H}+\mathrm{Al} 0.22 \mathrm{cmol}_{\mathrm{c}} \mathrm{dm}^{-3}$; and T $94.1 \mathrm{cmol}_{\mathrm{c}} \mathrm{dm}^{-3}$. Before seed planting, soil was fertilized with $\mathrm{N}$ and $\mathrm{P}$ according to the recommendation of Furtini Neto et al. (1999). Fertilization with K was carried out according to the treatments to be tested, using potassium chloride ( $\mathrm{KCl}$ ). Fifteen days after emergence (DAE), thinning was carried out, leaving the seedling more vigorous.

To reach the humidity levels, two pots were irrigated until the substrate saturation, and water was not added. Then, they were placed for leaching, and after observing that there was no more leaching, the pots were weighed on a scale, corresponding to the weight at $100 \%$ pc (substrate under pot capacity), and based on this, the other pots weight was determined. The substrate moisture level control was carried out every five days by weighing in digital balance $(0.1 \mathrm{~g})$, replacing the water necessary to reach the proposed moisture levels. Irrigation was performed between 4:30 pm and 5:00 pm, according to the water regime.

The treatments were distributed in a completely randomized design, in $3 \times 3$ factorial scheme, with three water levels (100\%pc - control, 50\%pc - moderate water deficit (MD), and $25 \% \mathrm{pc}$ - severe water deficit (SD)) and three doses of potassium (0, 97.5 and $\left.195 \mathrm{mg} \mathrm{dm}^{-3} \mathrm{~K}\right)$, with four replications. 
The water treatments started $45 \mathrm{DAE}$, and at the end of the experiment (135 DAE) morphological attributes were evaluated. Height was measured from the apical bud of the plant to the soil surface using a millimeter ruler, and the stem diameter was measured with a digital caliper (accuracy of $0.01 \mathrm{~mm}$ ).

In order to the biochemical analysis, $200 \mathrm{mg}$ of leaf fresh mass was macerated in $12 \mathrm{~mL}$ of MCW (methanol: chloroform: water), in 12:5:3 proportion, according to Bieleski et al. (1966). Leaf concentrations of total soluble sugars (SS) (YEMM et al., 1954), total free amino acids (AA) (YEMM et al., 1955) and proteins (PROT) (BRADFORD, 1976) were carried.

The data were subjected to analysis of variance (ANOVA), and the means compared using Tukey's test $(p \leq 0,05)$ in SISVAR statistical program, version 5.6 (FERREIRA, 2011).

\section{RESULTS AND DISCUSSION}

\section{Plant height and stem diameter}

The water deficit promoted plant height reduction in $M$. urundeuva and $M$. tenuiflora, in potassium fertilization treatments (Table 1). However, in L. ferrea, statistical equality was found between the control treatments and moderate water deficit, at doses 0 and $195 \mathrm{mg} \mathrm{dm}^{-3} \mathrm{~K}$. In addition, at $97.5 \mathrm{mg} \mathrm{dm}^{-3} \mathrm{~K}$, plants under moderate water deficit presented greater height. These data show that these plants tolerated the humidity condition of the substrate by $50 \% \mathrm{pc}$, regardless of the $\mathrm{K}$ supply. However, the reduction in water availability to $25 \%$ pc affected these plants more severely, with an average reduction of $44 \%$ in height, whereas in $M$. urundeuva and $M$. tenuiflora it was $38 \%$ and $34 \%$, respectively, compared to treatment at $50 \%$ pc.

Comparing the treatments of $\mathrm{K}$ (Tabel 1 ), within each water level, it is noticed that the supply of $\mathrm{K}$ did not positively influence the height of plants, in $M$. urundeuva and $M$. tenuiflora, occurring a reduction with the increase of K. Possibly the K soil content was sufficient for the plants to be able to grow properly, and that the addition of this nutrient to the soil may have caused an osmotic effect, resulting in a reduction in plant height. In contrast, in L. ferrea, the addition of $\mathrm{K}$ was not harmful to the plants because, even under conditions of water deficit, there was statistical equality in the height of the plants between the treatments of $\mathrm{K}$.

In the stem diameter, similar to that seen at plant height, there was a progressive reduction in $M$. urundeuva and $M$. tenuiflora with water deficit, in all potassium fertilization treatments (Table 2). In L. ferrea, statistical equality was found between the treatments $100 \% \mathrm{pc}$ and $50 \% \mathrm{pc}$, also at 0 and $195 \mathrm{mg} \mathrm{dm}^{-3} \mathrm{~K}$, and the largest stem diameter was obtained at $97.5 \mathrm{mg} \mathrm{dm}^{-3} \mathrm{~K}$ in plants at 50\%pc (Table 2). Comparing the $\mathrm{K}$ treatments, within each water level, reduction in the stem diameter in $M$. urundeuva is observed and no effect in M. tenuiflora with the supply of potassium. However, in L. ferrea, there was a positive influence, with an increase in stem diameter as the $\mathrm{K}$ level increased.

Decrease in the growth parameters reported above can be explained by the effects of low water availability in the processes of cell elongation and division, in addition to stomatal closure and a consequent 
decrease in photosynthesis and assimilates production. Water stress, depending on its intensity and duration, can cause a decrease in cells water content, resulting in less turgor pressure and a decrease in cell expansion and division and, consequently, in the growth of organs and plants (CHAVES et al., 2002; CHAVES et al., 2003). In addition, under conditions of low water availability, occur stomata closure, reducing water loss through transpiration (JIN et al., 2011; WANG et al., 2013; SHABALA et al., 2014), maintaining leaf water balance and preventing tissue death from dehydration (PEAK et al., 2004). However, such a strategy results in limiting the assimilation of $\mathrm{CO}_{2}$, resulting in a decrease in the photosynthetic rate and, consequently, in the production of carbohydrates and plant growth (PEEVA et al., 2009; CHAVES et al., 2009; HU et al., 2010). Reduction in plant growth due to water deficit is widely reported in the literature, and in Guazuma ulmifolia Lam plants, a $50 \%$ and $32 \%$ decrease in plant height and stem diameter, respectively, when water availability is reported imposed was $25 \%$ pc (SCALON et al., 2011). Likewise, water deficiency resulted in decreases of $44 \%$ and $48 \%$ in plant height and $25 \%$ and $31 \%$ in stem diameter, when the plants were kept at $25 \%$ pc, in relation to the control treatment in Cnidoscolus quercifolius (Pohl.) (RAMOS et al., 2019).

Tabel 1: Plants height (cm) of Myracrondruon urundeuva, Libidibia ferrea. and Mimosa tenuiflora under water levels and potassium fertilization.

\begin{tabular}{|c|c|c|c|}
\hline \multirow[t]{2}{*}{ Water level (\%pc) } & \multicolumn{3}{|c|}{ Myracrodruon urundeuva } \\
\hline & $0 \mathrm{mg} \mathrm{dm}^{-3} \mathrm{~K}$ & $97.5 \mathrm{mg} \mathrm{dm}^{-3} \mathrm{~K}$ & $195 \mathrm{mg} \mathrm{dm}^{-3} \mathrm{~K}$ \\
\hline 100 (control) & 28.9 aA & $28.2 \mathrm{aA}$ & $23.6 \mathrm{aA}$ \\
\hline 50 (MD) & $21.5 \mathrm{bA}$ & $19.4 \mathrm{bB}$ & $14.1 \mathrm{bB}$ \\
\hline 25 (SD) & $15.9 \mathrm{bA}$ & $10.4 \mathrm{cB}$ & $8.5 \mathrm{cB}$ \\
\hline \multirow[t]{2}{*}{ Water level (\%pc) } & \multicolumn{3}{|c|}{ Libidibia ferrea } \\
\hline & $0 \mathrm{mg} \mathrm{dm}^{-3} \mathrm{~K}$ & $97.5 \mathrm{mg} \mathrm{dm}^{-3} \mathrm{~K}$ & $195 \mathrm{mg} \mathrm{dm}^{-3} \mathrm{~K}$ \\
\hline 100 (control) & $72.5 \mathrm{aA}$ & $61.1 \mathrm{bA}$ & $66.0 \mathrm{aA}$ \\
\hline 50 (MD) & $69.6 \mathrm{aA}$ & $69.0 \mathrm{aA}$ & $64.6 \mathrm{aA}$ \\
\hline 25 (SD) & $38.5 \mathrm{bA}$ & $37.2 \mathrm{cA}$ & $38.4 \mathrm{bA}$ \\
\hline \multirow[t]{2}{*}{ Water level (\%pc) } & \multicolumn{3}{|c|}{ Mimosa tenuiflora } \\
\hline & $0 \mathrm{mg} \mathrm{dm}^{-3} \mathrm{~K}$ & $97.5 \mathrm{mg} \mathrm{dm}^{-3} \mathrm{~K}$ & $195 \mathrm{mg} \mathrm{dm}^{-3} \mathrm{~K}$ \\
\hline 100 (control) & $71.3 \mathrm{aA}$ & $61.2 \mathrm{aB}$ & $59.0 \mathrm{aB}$ \\
\hline 50 (MD) & $61.2 \mathrm{bA}$ & $55.1 \mathrm{bB}$ & $52.5 \mathrm{bB}$ \\
\hline 25 (SD) & $41.6 \mathrm{cA}$ & $39.6 \mathrm{cA}$ & $31.0 \mathrm{cB}$ \\
\hline
\end{tabular}

Capital letters compare $\mathrm{K}$ doses, within each water regime; lowercase letters compare water regimes in each dose of $\mathrm{K}$ (Tukey $P \leq 0,05)$.

Tabel 2: Stem diameter ( $\mathrm{mm}$ ) of Myracrondruon urundeuva, Libidibia ferrea, and Mimosa tenuiflora under water levels and potassium fertilization.

\begin{tabular}{|c|c|c|c|}
\hline \multirow[t]{2}{*}{ Water level (\%pc) } & \multicolumn{3}{|c|}{ Myracrodruon urundeuva } \\
\hline & $0 \mathrm{mg} \mathrm{dm}^{-3} \mathrm{~K}$ & $97.5 \mathrm{mg} \mathrm{dm}^{-3} \mathrm{~K}$ & $195 \mathrm{mg} \mathrm{dm}^{-3} \mathrm{~K}$ \\
\hline 100 (control) & $3.67 \mathrm{aA}$ & $2.99 \mathrm{aB}$ & $2.88 \mathrm{aB}$ \\
\hline 50 (MD) & $2.64 \mathrm{bA}$ & $2.00 \mathrm{bA}$ & $2.43 \mathrm{aA}$ \\
\hline 25 (SD) & $1.81 \mathrm{cA}$ & $1.74 \mathrm{cA}$ & $1.27 \mathrm{bB}$ \\
\hline \multirow[t]{2}{*}{ Water level (\%pc) } & \multicolumn{3}{|c|}{ Libidibia ferrea } \\
\hline & $0 \mathrm{mg} \mathrm{dm}^{-3} \mathrm{~K}$ & $97.5 \mathrm{mg} \mathrm{dm}^{-3} \mathrm{~K}$ & $195 \mathrm{mg} \mathrm{dm}^{-3} \mathrm{~K}$ \\
\hline 100 (control) & $2.82 \mathrm{aB}$ & $2.88 \mathrm{bB}$ & $3.57 \mathrm{aA}$ \\
\hline 50 (MD) & $2.03 \mathrm{aB}$ & $3.91 \mathrm{aA}$ & $3.77 \mathrm{aA}$ \\
\hline 25 (SD) & $1.12 \mathrm{cB}$ & $2.69 \mathrm{bA}$ & $2.90 \mathrm{bA}$ \\
\hline \multirow[t]{2}{*}{ Water level (\%pc) } & \multicolumn{3}{|c|}{ Mimosa tenuiflora } \\
\hline & $0 \mathrm{mg} \mathrm{dm}^{-3} \mathrm{~K}$ & $97.5 \mathrm{mg} \mathrm{dm}^{-3} \mathrm{~K}$ & $195 \mathrm{mg} \mathrm{dm}^{-3} \mathrm{~K}$ \\
\hline 100 (control) & $4.23 \mathrm{aA}$ & $4.59 \mathrm{aA}$ & $4.66 \mathrm{aA}$ \\
\hline 50 (MD) & $4.16 \mathrm{aA}$ & $4.47 \mathrm{aA}$ & $4.31 \mathrm{aA}$ \\
\hline 25 (SD) & $2.99 \mathrm{bA}$ & $2.86 \mathrm{bA}$ & $2.53 \mathrm{bA}$ \\
\hline
\end{tabular}

Capital letters compare $\mathrm{K}$ doses, within each water regime; lowercase letters compare water regimes in each dose of $\mathrm{K}$ (Tukey $P \leq 0,05)$. 
As for plant height (Table 1) and stem diameter reductions (Table 2) seen in $M$. urundeuva and $M$. tenuiflora as a consequence of $\mathrm{K}$ supply, it is believed that it may have been the result of an osmotic effect, which decreased the availability of water to plants, resulting in water deficit, and decreased plant growth. Possibly the $\mathrm{K}$ soil content was sufficient to maintain the plants growth and the additional supply of this nutrient resulted in damage to the growth parameters presented. Although it is an essential nutrient for plant growth, high doses of $\mathrm{K}$ can reduce growth due to osmotic effect or toxicity (FREIRE et al., 2003; MELO et al., 2020).

In contrast, in L. ferrea, the addition of $\mathrm{K}$ did not significantly affect the plants height (Table 1 ), but promoted an increase in the stem diameter (Table 2), possibly acting as an osmoregulator, allowing greater water absorption and facilitating the increase in stem diameter. Thus, it can be inferred that this species is more demanding in $\mathrm{K}$ than $M$. urundeuva and $M$. tenuiflora. The larger stem diameter can contribute to an increase in the vigor and quality of the seedlings, increasing the possibility of successful seedling after transplanting to the field. The $\mathrm{K}^{+}$acts as an osmoregulatory ion, decreasing the cells osmotic potential, promoting the absorption of water by the roots, which guarantees the maintenance of cell turgor and the continuity of important physiological processes in the plant such as photosynthesis (ANDRÉS et al., 2014; LU et al., 2019). A positive effect of $\mathrm{K}$ addiction by increasing the stem diameter was also reported in Eucalyptus grandis x Eucalyptus urophylla clones (D'AVILA et al., 2011), and Platymenia foliolosa Benth (DUARTE et al., 2015).

\section{Organics solutes}

There was a significant effect of treatments in AA, but in isolation, in M. urundeuva and L. ferrea. There is statistical equality between the treatments $100 \% \mathrm{pc}$ and $25 \% \mathrm{pc}$, with the highest concentration of AA in plants at 50\%pc, in M. urundeuva, while in L. ferrea, it was verified at 25\%pc (Table 3), representing an average increase of $55 \%$ in relation to other water treatments. Regarding potassium fertilization, there was a progressive increase in $\mathrm{AA}$ with an increase in the dose of $\mathrm{K}$ in $\mathrm{M}$. urundeuva, corresponding to an increase of $35 \%$ and $39 \%$, respectively in treatments 97.5 and $195 \mathrm{mg} \mathrm{dm}^{-3} \mathrm{~K}$, compared to treatment who did not receive $\mathrm{K}$ supplementation (Table 4).

Tabel 3: Total free amino acids content in Myracrodruon urundeuva e Libidibia ferrea under water levels.

\begin{tabular}{lll}
\hline \multirow{2}{*}{ Water level (\%pc) } & Aminoacids $(\mu \mathrm{g} \mathrm{gMF}-1)$ & \\
\cline { 2 - 3 } & Myracrodruon urundeuva & Libidibia ferrea \\
\hline $\mathbf{1 0 0}$ (control) & $467.9 \mathrm{~b}$ & $580.4 \mathrm{~b}$ \\
$\mathbf{5 0}$ (MD) & $599.3 \mathrm{a}$ & $552.2 \mathrm{~b}$ \\
$\mathbf{2 5}$ (SD) & $419.4 \mathrm{C}$ & $875.3 \mathrm{a}$ \\
\hline
\end{tabular}

Letters compare water regimes (Tukey $\mathrm{P} \leq 0,05$ ).

Tabel 4: Total free amino acids content in Myracrodruon urundeuva under potassium fertilization.

\begin{tabular}{ll}
\hline $\mathbf{K}\left(\mathbf{m g ~ d m}^{-3} \mathrm{~K}\right)$ & Aminoacids $\left(\mu \mathrm{gMF}^{-1}\right)$ \\
\hline $\mathbf{0}$ & $356.1 \mathrm{c}$ \\
$\mathbf{9 7 . 5}$ & $545.3 \mathrm{~b}$ \\
$\mathbf{1 9 5}$ & $585.2 \mathrm{a}$ \\
\hline
\end{tabular}

Letters compare potassium doses (Tukey $(\mathrm{P} \leq 0,05)$. 
Regarding the concentration of proteins, the plants of $M$. urundeuva maintained at the water regime $50 \%$ pc presented the highest values, with statistical equality between the treatments $100 \%$ pc and $25 \%$ pc (Table 5). Regarding potassium fertilization, plants at $97.5 \mathrm{mg} \mathrm{dm}^{-3} \mathrm{~K}$ had the lowest protein concentration, with statistical equality between treatments 0 and $195 \mathrm{mg} \mathrm{dm}^{-3} \mathrm{~K}$.

In L. ferrea, there was no statistical difference between water levels, in treatments 0 and $195 \mathrm{mg} \mathrm{dm}$ ${ }^{3} \mathrm{~K}$, and at $97.5 \mathrm{mg} \mathrm{dm}^{-3} \mathrm{~K}$, in control plants and at 25\%pc the PROT values were higher than those under 50\%pc (Table 6).

Tabel 5: Protein content in Myracrodruon urundeuva under water levels and potassium fertilization.

\begin{tabular}{|c|c|}
\hline Water level (\%pc) & Protein ( $\left.\mu \mathrm{g}_{\mathrm{gMF}} \mathrm{MM}^{-1}\right)$ \\
\hline 100 (control) & $19.43 \mathrm{c}$ \\
\hline 50 (MD) & $23.65 \mathrm{a}$ \\
\hline 25 (SD) & $21.19 \mathrm{~b}$ \\
\hline Doses de $\mathrm{K}\left(\mathrm{mg} \mathrm{dm}^{-3} \mathrm{~K}\right)$ & Protein ( $\left.\mu \mathrm{g}_{\mathrm{gMF}} \mathrm{gM}^{-1}\right)$ \\
\hline 0 & $22.95 a$ \\
\hline 97.5 & $18.91 \mathrm{~b}$ \\
\hline 195 & $22.42 \mathrm{a}$ \\
\hline
\end{tabular}

Letters compare water regimes and potassium doses (Tukey $\mathrm{P} \leq 0,05$ ).

Tabel 6: Protein content in Libidibia ferrea e Mimosa tenuiflora under water levels and potassium fertilization.

\begin{tabular}{|c|c|c|c|}
\hline \multirow[t]{2}{*}{ Water level (\%pc) } & \multicolumn{3}{|c|}{ Libidibia ferrea } \\
\hline & $0 \mathrm{mg} \mathrm{dm}^{-3} \mathrm{~K}$ & $97.5 \mathrm{mg} \mathrm{dm}^{-3} \mathrm{~K}$ & $195 \mathrm{mg} \mathrm{dm}^{-3} \mathrm{~K}$ \\
\hline 100 (control) & $21.7 \mathrm{aB}$ & $24.2 \mathrm{aA}$ & $19.2 \mathrm{aB}$ \\
\hline 50 (MD) & $22.6 \mathrm{aA}$ & $19.6 \mathrm{bB}$ & $19.4 \mathrm{aB}$ \\
\hline 25 (SD) & $20.3 \mathrm{aA}$ & $22.3 \mathrm{aA}$ & $20.6 \mathrm{aA}$ \\
\hline \multirow[t]{2}{*}{ Water level (\%pc) } & \multicolumn{3}{|c|}{ Mimosa tenuiflora } \\
\hline & $0 \mathrm{mg} \mathrm{dm}^{-3} \mathrm{~K}$ & $97.5 \mathrm{mg} \mathrm{dm}^{-3} \mathrm{~K}$ & $195 \mathrm{mg} \mathrm{dm}^{-3} \mathrm{~K}$ \\
\hline 100 (control) & $20.4 \mathrm{aA}$ & $24.8 \mathrm{aA}$ & $21.1 \mathrm{bA}$ \\
\hline 50 (MD) & $22.9 \mathrm{aB}$ & $22.4 \mathrm{aB}$ & $27.1 \mathrm{aA}$ \\
\hline 25 (SD) & $23.9 \mathrm{aA}$ & $19.8 \mathrm{aA}$ & $21.5 \mathrm{bA}$ \\
\hline
\end{tabular}

Capital letters compare $\mathrm{K}$ doses, within each water regime; lowercase letters compare water regimes in each dose of $\mathrm{K}$ (Tukey $P \leq 0,05)$.

An increase in $\mathrm{K}$ doses caused a reduction in PROT, except for those maintained at $25 \% \mathrm{pc}$, in which there was statistical equality between K. doses. In M. tenuiflora, a significant effect of water levels was observed only in plants that received $195 \mathrm{mg} \mathrm{dm}^{-3} \mathrm{~K}$, with a higher concentration of PROT at 50\%pc. In relation to $\mathrm{K}$, an increase in protein concentration was observed as the dose of this nutrient increased, only in plants maintained under moderate water deficit (Table 6).

In relation to SS, a significant effect was observed only in the potassium doses in $M$. tenuiflora, with reduction as the dose supplied increased (Table 7). Compared with treatment without potassium, there was a decrease of $36 \%$ and $43 \%$ in the concentration of AST, respectively, in treatments 97.5 and $195 \mathrm{mg} \mathrm{dm}^{-3} \mathrm{~K}$.

Tabel 7: Soluble sugar content in Mimosa tenuiflora under potassium fertilization.

\begin{tabular}{ll}
\hline $\mathrm{K}\left(\mathrm{mg} \mathrm{dm}^{-3} \mathrm{~K}\right)$ & Soluble sugar $\left(\mu \mathrm{gMF}^{-1}\right)$ \\
\hline $\mathbf{0}$ & $43.13 \mathrm{a}$ \\
$\mathbf{9 7 . 5}$ & $27.41 \mathrm{~b}$ \\
$\mathbf{1 9 5}$ & $24.61 \mathrm{~b}$ \\
\hline
\end{tabular}

Letters compare potassium doses (Tukey $\mathrm{P} \leq 0,05$ ).

In this study, it seems that there was no osmotic adjustment capable of maintaining plant growth, as in treatments where solutes increased (Tables 3 to 6 ) there was a reduction in growth (Tables 1,2$)$. Possibly, 
the accumulation of solutes only ensured that the plants kept the tissues hydrated, preventing their death, allowing the maintenance of vital biochemical processes. The accumulation of osmotically active solutes guarantees the absorption of water by plants, providing cell turgor and the maintenance of cell metabolism, preventing the death of the plant (FLEXAS et al., 2002; COSTA et al., 2015). However, the type and concentration of the solute seem to vary from species to species, and plants can accumulate or degrade solutes depending on stress and their own physiological capacity/plasticity. Silva (2011) reported a significant increase in the protein content of Ziziphus joazeiro (Mart.) plants submitted to water stress, whereas Costa et al. (2015) found that water deficiency in M. urundeuva did not influence the concentration of these solutes. In contrast, in Tectona grandis (L.) Lechinoski et al. (2007) reported a 95\% reduction in the total soluble protein content, and attributed it to an increase in proteolytic activity or a decrease in their synthesis. External factors such as reduced water availability may result in increased cell protein biosynthesis (CHERNYAD'EV, 2005), considered as stress proteins, which are highly hydrophilic proteins, acting as stabilizers, preventing enzymatic inactivation (KOSOVÀ et al., 2010; CHIAPPETTA et al., 2015).

Elevations in the concentrations of total amino acids and total soluble sugars under water deficiency conditions were verified in Z. joazeiro (SILVA, 2011), and Moringa oleifera Lam (RIVAS et al., 2013). It has been shown that proline is the main amino acid that accumulates under water deficient conditions, as reported by Albuquerque et al. (2013) in Khaya ivorensis (A. Chev.) and Oliveira et al. (2017) in Anadenanthera colubrina (Vell.) Brenan. This accumulation is seen by some researchers as a compensatory strategy, because proline is a beneficial osmotic regulator, because, in addition to promoting osmotic regulation, it is able to stabilize protein synthesis by eliminating reactive oxygen species (ROS) (KISHOR et al., 2014). Proline has other important characteristics such as high solubility, which makes it an important osmotic agent (LERUDULIER et al., 1984), and is compartmentalized in the mitochondria releasing energy in the form of FADH ${ }_{2}$ and NADPH (SZABADOS et al., 2010).

\section{CONCLUSIONS}

Under water deficit condition, Myracrocruon urundeuva and Mimosa tenuiflora plants had reduction in growth, regardless of the added potassium, while potassium fertilization with $97.5 \mathrm{mg} \mathrm{dm}^{-3} \mathrm{~K}$ favored Libidibia ferrea plants, especially when kept under moderate water deficit. The water deficit promotes total free amino acids and soluble proteins accumulations in Myracrocruon urundeuva and Libidibia ferrea.

\section{REFERENCES}

ALBUQUERQUE, M. P. F.; MORAES, F. K. C.; SANTOS, R. I. N.; CASTRO, G. L. S.; RAMOS, E. M. L. S.; PINHEIRO, H. A. Ecofisiologia de plantas jovens de mogno-africano submetidas a déficit hídrico e reidratação. Pesquisa Agropecuária Brasileira, Brasília, v.48, n.1, p.9-16, 2013. DOI: http://doi.org/10.1590/S0100-204X2013000100002

ALLEN, C. D.; MACALADY, A. K.; CHENCHOUNI, H.; BACHELET, D.; MCDOWELL, N.; VENNETIER, M.; KITZBERGER, T.; RIGLING, A.; BRESHEARS, D. D.; HOGG, E. H.; GONZALEZ, P.; FENSHAM, R.; ZHANG, Z.; CASTRO, J.; DEMIDOVA, N.; LIM, J.
H.; ALLARD, G.; RUNNING, S. W.; SEMERCI, A.; COBB, N.. A global overview of drought and heat-induced tree mortality reveals emerging climate change risks for forests. Forest Ecology and Management, v.259, n.4, p.660-684, 2010. DOI: http://doi.org/10.1016/i.foreco.2009.09.001

ALVES, E. U.; BRUNO, R. L. A.; OLIVEIRA, A. P.; ALVES, A. U.; ALVES, A. U.. Escarificação ácida na superação da dormência de sementes de pau ferro (Caesalpinea ferrea Mart.ex Tu. var. leiostachya Benth.) Revista Caatinga, Mossoró, v.22, n.1, p.37-47, 2009a. 
ALVES, J. J. A.; ARAÚJO, M. A.; NASCIMENTO, S. S. Degradação da Caatinga: uma investigação ecogeográfica. Revista Caatinga, Mossoró, v.22, n.3, p.126-135, 2009 b.

ANDRÉS, Z.; PÉREZ-HORMAECHE, J.; LEIDI, E. O.; SCHLÜCKING, K.; STEINHORST, L.; MCLACHLAN, D. H.; SCHUMACHER, K.; HETHERINGTON, A. M.; KUDLA, J.; CUBERO, B.; PARDO, J. M.. Control of vacuolar dynamics and regulation of stomatal aperture by tonoplast potassium uptake. PNAS, v.111, n.17, e1806-E1814, 2014. DOI: http://doi.org/10.1073/pnas.1320421111

AZEVÊDO, S. M. A.; BAKKE, I. A.; BAKKE, O. A.; FREIRE, A. L. O.. Crescimento de plântulas de jurema preta (Mimosa tenuiflora (Wild) Poiret) em solos de áreas degradadas da caatinga. Engenharia Ambiental, Espírito Santo do Pinhal, v.9, n.3, p.150-160, 2012.

BAKKE, I. A.; FREIRE, A. L. O.; BAKKE, O. A.; ANDRADE, A. P.; BRUNO, R. L. A.. Water and sodium chloride effects on Mimosa tenuiflora (Willd.) Poiret seed germination. Revista Caatinga, Mossoró, v.19, n.3, p.261-267, 2006.

BARROS, I. O.; SOARES, A. A.. Adaptações anatômicas em folhas de marmeleiro e velame da caatinga brasileira. Revista Ciência Agronômica, Fortaleza, v.44, n.1, p.192-198, 2013. DOI: http://doi.org/10.1590/S180666902013000100024

BATTIE-LACLAU, P.; LACLAU, J. P.; BERI, C.; MIETTON, L.; MUNIZ, M. R. A.; ARENQUE, B. C.; PICCOLO, M. D. C.; JORDÂNIA-MEILLE, L.; BOUILLET, J. P.; NOUVELLON, Y.. Photosynthetic and anatomical responses of Eucalyptus grandis leaves to potassium and sodium supply in a field experiment. Plant, Cell \& Environment, v.37, n.1, p.70-81, 2014. DOI: http://doi.org/10.1111/pce.12131

BIELESKI, R. I.; TURNER, N. A.. Separation and estimation of amino acids in crude plants extracts by thin-layer electrophoresis and chromatography. Analytical Biochemistry, v.17, p.278-293, 1966.

BRADFORD, M. M.. A rapid and sensitive method for the quantitation of microgram quantities of protein utilizing the principle of protein binding. Analytical Biochemistry, v.72, p.248-254, 1976

BRASIL. Ministério do Meio Ambiente. Instrução Normativa N. 06, de 23 de setembro de 2008. MMA, 2008.

CARVALHO, P. E. R.. Espécies arbóreas brasileiras. Colombo, 2003.

CHAVES, M. M.; FLEXAS, J.; PINHEIRO, C.. Photosynthesis under drought and salt stress: regulation mechanisms from whole plant to cell. Annals of Botany, v.103, n.4, p.551-560, 2009. DOI: http://doi.org/10.1093/aob/mcn125

CHAVES, M. M.; MAROCO, J. P.; PEREIRA, J. S. Understanding plant responses to drought - from genes to the whole plant. Functional Plant Biology, v.30, n.3, p.239264, 2003. DOI: http://doi.org/10.1071/FP0207

CHAVES, M. M.; PEREIRA, J. S.; MAROCO, J.; RODRIGUES, M. L.; RICARDO, C. P. P; OSÓRIO, M. L.; CARVALHO, I.; FARIA, T.; PINHEIRO, C.. How plants cope with water stress in the field?
Photosynthesis and growth. Annals of Botany, v.89, n.7, p.907-916, 2002. DOI: http://doi.org/10.1093/aob/mcf105

CHERNYAD'EV, I. I.. Effect of water stress on the photosynthetic apparatus of plants and the protective role of cytokinins: A review. Applied Biochemistry and Microbiology, v.41, n.2, p.115-128, 2005. DOI: http://doi.org/10.1007/s10438-005-0021-9

CHIAPPETTA, A.; MUTO, A.; BRUNO, L.; WOLOSZYNSK, M.; VAN LIJSEBETTENS, M.; BITONTI, M. B.. A dehydrin gene isolated from feral olive enhances drought tolerance in Arabidopsis transgenic plants. Front Plant Science, v.6, p.115, 2015. DOI: http://doi.org/10.3389/fpls.2015.00392

COSTA, A. S.; FREIRE, A. L. O.; BAKKE, I. A.; PEREIRA, F. H. F. Respostas fisiológicas e bioquímicas de plantas de aroeira (Myracrodruon urundeuva Allemão) ao déficit hídrico e posterior recuperação. Irriga, Botucatu, v.20, n.4, p.705-717, 2015. DOI: http://doi.org/10.15809/irriga.2015v20n4p705

D'AVILA, F. S.; PAIVA, H. N.; LEITE, H. G.; BARROS, N. F.; LEITE, F. P.. Efeito do potássio na fase de rustificação de mudas clonais de eucalipto. Revista Árvore, Viçosa, v.35, n.1, p.13-19, 2011. DOI: http://doi.org/10.1590/S010067622011000100002

DICHIO, B.; MARGIOTTA, G.; XILOYANNIS, C.; BUFO, S. A.; SOFO, A.; CATALD, T. R. I.. Changes in water status and osmolyte contents in leaves and roots of olive plants (Olea europaea L.) subject to water deficit. Trees, v.23, p.247-256, 2009. DOI: http://doi.org/10.1007/s00468-008-0272-1

DUARTE, M. L.; PAIVA, H. N. D.; ALVES, M. O.; FREITAS, A. F. D.; MAIA, F. F.; GOULART, L. M. L.. Crescimento e qualidade de mudas de vinhático (Platymenia foliolosa Benth.) em resposta à adubação com potássio e enxofre. Ciência Florestal, Santa Maria, v.25, n.1, p.221-229, 2015. DOI: http://doi.org/10.1590/1980-509820152505221

FERREIRA, D. F.. Sisvar: versão 5.6. Lavras: UFLA, 2011.

FLEXAS, J.; MEDRANO, H.. Drought-inhibition of photosynthesis in C3 plants: stomatal and non-stomatal limitations revisited. Annals of Botany, v.89, n.2, p.183-189, 2002. DOI: http://doi.org/10.1093/aob/mcf027

FREIRE, M. B. G. S.; RUIZ, H. A.; RIBEIRO, M. R.; FERREIRA, P. A.; VICTOR, H.; ALVAREZ, V.; FREIRE, F. J.. Condutividade hidráulica de solos de Pernambuco em resposta à condutividade elétrica e RAS da água de irrigação. Revista Brasileira de Engenharia Agrícola e Ambiental, Campina Grande, v.7, n.1, p.45-52, 2003.

FURTINI NETO, A. E.; RESENDE, A.; VALE, F. R.; FAQUIM, V.; FERNANDES, L. A.. Acidez do solo, crescimento e nutrição mineral de algumas espécies arbóreas na fase de muda. Cerne, Lavras, v.5, n.2, p.1-12, 1999.

GUSMÃO, L. F. P.; QUEIROZ, L. P; QUIJANO, F. R. B; JUNCÁ, F. A; OLIVEIRA, R. P; BASEIA, I. G.. Caatinga: Diversidade na Adversidade do Semiárido Brasileiro. In: Conhecendo a Biodiversidade. Brasília: Vozes, 2016. p.101-111.

HU, L.; WANG, Z.; HUANG, B.. Diffusion limitations and metabolic factors associated with inhibition and recovery of photosynthesis from drought stress in a C3 perennial grass 
species. Physiologia Plantarum, v.139, n.1, p.93-106, 2010. DOI: http://doi.org/10.1111/i.1399-3054.2010.01350.x

IPCC. Intergovernmental Panel on Climate Change. Climate Change 2014: Synthesis Report. Contribution of Working Groups I, II and III to the Intergovernmental Panel on Climate Change Fifth Assessment Report of the [Core Writing Team]. Geneva: IPCC, 2014.

JAMNICKÁ, G.; FLEISCHER, J. R. P.; KONÔPKOVÁ, A.; PŠIDOVÁ, E.; KUCEROVÁ, J; KURJAK, D.; ŽIVCÁK, M.; DITMAROVÁ, L.. Norway spruce (Picea abies L.) provenances use different physiological strategies to cope with water deficit. Forests, v.10, n.8, p.651-667, 2019. DOI: http://doi.org/10.3390/f10080651

JESUS, J. B.; FERREIRA, R. A; GAMA, D. C.; GOES, J. H. A.. Estabelecimento de espécies florestais nativas via semeadura direta no rio Piauitinga-Sergipe. Floresta e Ambiente, Seropédica, v.24, n.e20150288, 2017. DOI: http://doi.org/10.1590/2179-8087.028815

JIN, S. H.; HUANG, J. Q.; LI, X. Q.; ZHENG, B. S.; WU, J. S.; WANG, Z. J.; LIU, G. H.; CHEN, M.. Effects of potassium supply on limitations of photosynthesis by mesophyll diffusion conductance in Carya cathayensis. Plant Physiology, v.31, n.10, p.1142-1151, 2011. DOI: http://doi.org/10.1093/treephys/tpr095

KISHOR, P. B. K.; SREENIVASULU, N.. Is proline accumulation per se correlated with stress tolerance or is proline homoeostasis a more critical issue? Plant, Cell and Environment, v.37, n.2, p.300-311, 2014. DOI: http://doi.org/10.1111/pce.12157

KOSOVÀ, K.; PRASIL, I. T.; PRASILOVÀ, P.; VITÀMVÀS, P.; CHRPOVÁ, J.. The development of frost tolerance and DHN5 protein accumulation in barley (Hordeum vulgare) doubled haploid lines derived from Atlas $68 \times$ Igri cross during cold acclimation. Journal of Plant Physiology, v.167, n.5, p.343350, 2010. DOI: http://doi.org/10.1016/j.jplph.2009.09.020

LECHINOSKI, A.; FREITAS, J. N. M.; CASTRO, D. S.; LOBATO, A. K. S.; OLIVEIRA NETO, C. F.; CUNHA, R. L. M.. Influência do estresse hídrico nos teores de proteínas e aminoácidos solúveis totais em folhas de teca (Tectona grandis L. F). Revista Brasileira de Biociências, Porto Alegre, v.5, n.2, p.927-929, 2007.

LERUDULIER, D.; STROM, A. R.; DANDEKAR, A. M.; SMITH, L. T.; VALENTAINE, R. C.. Molecular biology of osmoregulation. Science, v.224, n.4653, p.1064-1068, 1984. DOI: http://doi.org/10.1126/science.224.4653.1064

LORENZI, H.. Árvores brasileiras: manual de identificação e cultivo de plantas arbóreas do Brasil. 5 ed. Nova Odessa: Instituto Plantarum, 2008.

LU, Z.; HU, W.; REN, T.; ZHU, C.; LI, X.; CONG, R.; GUO, S.; LU, $J$. Impact of $K$ deficiency on leaves and siliques photosynthesis via metabolomics in Brassica napus. Environmental and Experimental Botany, v.158, p.89-98, 2019. DOI: http://doi.org/10.1016/j.envexpbot.2018.11.008

LUCENA, R. F.; FARIAS, D. C.; CARVALHO, T. K. N.; LUCENA, C. M.; VASCONCELOS NETO, C. F. A.; ALBUQUERQUE, U. P.. Uso e conhecimento da aroeira (Myracrodruon urundeuva) por comunidades tradicionais no semiárido brasileiro.

Sitientibus, Série Ciências Biológicas, Feira de Santana, v.11, n.2, p.255-264, 2011.

MAIA, G. N.. Caatinga: árvores e arbustos e suas utilidades. São Paulo: D \& Z, 2004.

MELO, R. R.; GONÇALVES, S. L. S.; BACCARIN, F. J. B.; VASCONCELOS, W. A.; MIRANDA, C. C.. Influência de altas dosagens de cloreto de potássio no desenvolvimento de espécies em cultivo hidropônico. PUBVET, v.14, n.14, a588, p.1-9, 2020. DOI:

http://doi.org/10.31533/pubvet.v14n4a558.1-9

MONDINI, D. P. S.; SANTIAGO, E. F.; DANIEL, O.; SILVA, J. V.; FRANCISCO, N. S.. Características fisiológicas de mudas de Eucalyptus sp sob diferentes concentrações de potássio. Agrarian, Dourados, v.12, n.43, p.40-47, 2019. DOI: http://doi.org/10.30612/agrarian.v12i43.4065

MONTEIRO, J. M.; LINS NETO, E. M. F.; AMORIM, E. L. C.; STRATTMANN, R. R.; ARAÚJO, E. L.; ALBUQUERQUE, U. P. Teor de taninos em três espécies medicinais arbóreas simpátricas da caatinga. Revista Árvore, Viçosa, v.29, n.6, p.999-1005, 2005. DOI: http://doi.org/10.1590/S0100$\underline{67622005000600020}$

NIO, S. A.; CAWTHRAY, G. R.; WADE, L. J.; COLMER, T. D. Pattern of solutes accumulation during leaf osmotic adjustment as related to duration of water deficit for wheat at the reproductive stage. Plant Physiology and Biochemistry, v.49, n.10, p.1126-1137, 2011. DOI: http://doi.org/10.1016/i.plaphy.2011.05.011

OLIVEIRA, A. F.; BATISTA, J. S.; PAIVA, E. S.; SILVA, A. E.; FARIAS, Y. J. M. D.; DAMASCENO, C. A. R.; BRITO, P. D.; QUEIROZ, S. A. C.; RODRIGUES, C. M. F.; FREITAS, C. I. A. Avaliação da atividade cicatrizante do jucá (Caesalpinia ferrea Mart. ex Tul. var. ferrea) em lesões cutâneas de caprinos. Revista Brasileira de Plantas Medicinais, Paulínia, v.12, n.3, p.302-310, 2010.

OLIVEIRA, E.. Características anatômicas, químicas e térmicas da madeira de três espécies de maior ocorrência no semi-árido nordestino. Tese (Doutorado em Ciências Florestais) - Universidade Federal de Viçosa, Viçosa, 2003.

OLIVEIRA, J. L. S.; SILVA, E.. Efeitos do estresse osmótico no desenvolvimento inicial de Phaseolus vulgaris L. Iniciação Científica CESUMAR, v.21, n.1, p.55-60, 2019. DOI: http://doi.org/10.17765/1518-1243.2019v21n1p55-60

OLIVEIRA, M. T.; SOUZA, G. M.; PEREIRA, S.; OLIVEIRA, D. A.; FIGUEIREDO-LIMA, K. V.; ARRUDA, E.; SANTOS, M. G.. Seasonal variability in physiological and anatomical traits contributes to invasion success of Prosopis juliflora in tropical dry forest. Tree Physiology, v.37, n.3, p.326-337, 2017. DOI: http://doi.org/10.1093/treephys/tpw123

PRADO, R. M.. Nutrição de plantas. Ouro Fino: Agronômica Ceres, 2008.

PEAK, D.; WEST, J. D.; MESSINGER, S. M.; MOTT, K. A.. Evidence for complex, collective dynamics and emergent, distributed computation in plants. PNAS, v.101, n.4, p.918922, 2004. DOI: http://doi.org/10.1073/pnas.0307811100 
PEEVA, V.; CORNIC, G.. Leaf photosynthesis of Haberlea rhodopensis before and during drought. Environmental and Experimental Botany, v.65, n.2-3, p.310-318, 2009. DOI: http://doi.org/10.1016/j.bbr.2011.03.031

QUEIROZ, L. P.; FRANÇA, F.; GIULIETTI, A. M.; MELO, E.; GONÇALVES, C. N.; FUNCH, L. S.; HARLEY, R. M.; FUNCH, R. R.; SILVA, T. S.. Caatinga. In: JUNCÁ, F. A.; FUNCH, L.; ROCHA, W.. Biodiversidade e Conservação da Chapada Diamantina. Brasília: Ministério do Meio Ambiente, 2005.

RAMOS, F. R.; FREIRE, A. L. O.. Growth and gas exchange of Cnidoscolus quercifolius fertilized with potassium and under water deficit. Journal of Agricultural Science, v.11, n.11, p.23-29, 2019. DOI: http://doi.org/10.5539/jas.v11n11p23

RHODES, D.; HANSON, A. D.. Quaternary ammonium and tertiary sulfonium compounds in higher plants. Annual Review of Plant Physiology and Plant Molecular Biology, v.44, p.357-84, 1993.

RIBEIRO, D. A. I.; MACÊDO, D. G. I.; OLIVEIRA, L. G. S. I.; SARAIVA, M. E. I.; OLIVEIRA, S. F. I.; SOUZA, M. M. A. I.; MENEZES, I. R. A.. Potencial terapêutico e uso de plantas medicinais em uma área de Caatinga no estado do Ceará, nordeste do Brasil. Revista Brasileira de Plantas Medicinais, Paulínia, v.16, n.4, p.912-930, 2014. DOI: http://doi.org/10.1590/1983-084X/13-059

RIVAS, R.; OLIVEIRA, M. T.; SANTOS, M. G.. Three cycles of water deficit from seed to young plants of Moringa oleifera woody species improves stress tolerance. Plant Physiology and Biochemistry, v.63, p.200-208, 2013. DOI: http://doi.org/10.1016/j.plaphy.2012.11.026

SAMPAIO, F. C.; PEREIRA, M. S. V.; DIAS, C. S.; COSTA, V. C. O.; CONDE, N. C.; BUZALAF, M. A.. In vitro antimicrobial activity of Caesalpinia ferrea Martius fruits against oral pathogens. Journal of Ethnopharmacology, v.124, n.2, p.289-294, 2009. DOI: http://doi.org/10.1016/j.jep.2009.04.034
SCALON, S. P. Q.; MUSSUY, R. M.; EUZEBIO, V. L. M.; KODAMA, F. M.; KISSMANN, C.. Estresse hídrico no metabolismo e crescimento inicial de mudas de mutambo (Guazuma ulmifolia Lam.). Ciência Florestal, Santa Maria, v.21, n.4, p.655-662, 2011. DOI: http://doi.org/10.5902/198050984510

SHABALA, S.; POTTOSIN, I.. Regulation of potassium transport in plants under hostile conditions: implications for abiotic and biotic stress tolerance. Physiologia Plantarum, v.151, n.3, p.257-279, 2014. DOI: http://doi.org/10.1111/ppl.12165

SILVA, M. A. V.. Caracterização fisioanatômica e bioquímica do Juazeiro (Ziziphus joazeiro Mart.) submetido ao déficit hídrico. Tese (Doutorado em Botânica) - Universidade Federal Rural de Pernambuco, Recife, 2011.

SZABADOS, L.; SAVOURÉ, A.. Proline: a multifunctional aminoacid. Trends in Plant Science, v.15, n.2, p.89-97, 2010. DOI: http://doi.org/10.1016/j.tplants.2009.11.009

TAIZ, L.; ZEIGER, E.. Fisiologia vegetal. 5 ed. Porto Alegre: Artmed, 2013.

TROVÃO, D. M. B. M; FERNANDES, P. D.; ANDRADE, L. A.; DANTAS NETO, J.. Variações sazonais de aspectos fisiológicos de espécies da Caatinga. Revista Brasileira de Engenharia Agrícola e Ambiental, Campina Grande, v.11, n.3, p.307-311, 2007. DOI: http://doi.org/10.1590/S141543662007000300010

WANG, M.; ZHENG, Q.; SHEN, Q.; GUO, S.. The critical role of potassium in plant stress response. International Journal of Molecular Science, v.14, n.4, p.7370-7390, 2013. DOI: http://doi.org/10.3390/ijms14047370

YEMM, E. W.; COCKING, E. C.. The determination of amino acid with ninhydrin. Analyst, v.80, p.209-213, 1955.

YEMM, E. W.; WILLIS, A. J.. The estimation of carbohydrates in plant extracts by anthrone. Biochemical Journal, v.57, p.508-14, 1954.

A CBPC - Companhia Brasileira de Produção Científica (CNPJ: 11.221.422/0001-03) detém os direitos materiais desta publicação. Os direitos referem-se à publicação do trabalho em qualquer parte do mundo, incluindo os direitos às renovaç̃ões, expansões e disseminações da contribuiç̃o, bem como outros direitos subsidiários. Todos os trabalhos publicados eletronicamente poderão posteriormente ser publicados em coletâneas impressas sob coordenação da Sustenere Publishing, da Companhia Brasileira de Produção Científica e seus parceiros autorizados. Os (as) autores (as) preservam os direitos autorais, mas não têm permissão para a publicação da contribuição em outro meio, impresso ou digital, em português ou em tradução. 